\title{
EVALUATION OF CORPORATE SOCIAL RESPONSIBILITY PROGRAM IMPLEMENTATION IN BOGOR PDAM TIRTA PAKUAN, WEST JAVA PROVINCE
}

\author{
Ismartaya \\ State University of jakarta \\ Ismantaya.unj@gmail.com
}

\begin{abstract}
The purpose of this research is to determined whether the evaluation corporate social responsibility program implementation in Bogor PDAM Tirta Pakuan has been implemented in accordance with the vision, mission, and objectives of the company. PDAM Tirta Pakuan has a vision of CSR as a pioneer in the implementation of social responsibility in Bogor city especially and Indonesia in generally. Through this vision, PDAM Tirta Pakuan Bogor city, would really seriously on the implementation of the CSR programs. Based on these purposes, this research is done by evaluating the CSR programs which implemented by PDAM Tirta Pakuan Bogor city and use CIPP evaluation model to conduct an evaluation of the program. The type which used on this research is evaluation research with use qualitative approach. The source of information used is the Chief Executive of CSR PDAM Tirta Pakuan Bogor. Data collected by the observation, interview and documentation. Test validity of this research by using triangulation technique, while data analysis is done by reducing the data, presenting and concluding. The result shows that the program Tirta Pakuan care as the company's strategy goes according to the purposes and plans that have been made by the company.
\end{abstract}

Keywords: evaluation, corporate social responsibility, CIPP Model

Corporate Social Responsibility (CSR) is an ongoing commitment to the corporate world to act ethically and contribute to economic development of the local community or society in generalty large, along with the increase of the living standards of workers and their families (Frankl, 2007). The concept of CSR is inseparable from sustainable development (sustainable development). Sustainable development, not only understood as concern for the environment, but also include economic and social development. The Implementation of CSR appropriately in the community will maintain the quality of the environment, improving the quality of human resources, and enhance the ability of the local economy. The company has a social responsibility as stipulated in the Law of the Republic of Indonesia No.40 of 2007 regarding comany in Chapter IV, Social and Environmental Responsibility in article 74 provides:

1. The Company which conducting its business activities in the field and / or related to the natural resources required to implement the Social and Environmental Responsibility.

2. Social and Environmental Responsibility as referred to in paragraph (1) an obligation of the Company's budgeted and accounted for as an expense of the Company which are carried out with due regard to decency and fairness.

3. The Company which did not carry out the obligations referred to in paragraph (1) be sanctioned in accordance with the provisions of the legislation.

4. Further provisions regarding Social Responsibility and Environmental regulated by Government Regulation.

In 2012 the government published Government Regulation No. 47 Year 2012 abaut Social and Environmental Responsibility Company Limited. This regulation was finally recognized that CSR is a company authorized by stating that the preparation and implementation of CSR is the authority of the board of directors or the company's AGM. 
The setting of Corporate Social Responsibility in Indonesia is not only imposed on private companies, but also to state that carries on business in the interest of the public. CSR arrangements for SOEs can be found in the Law on State Enterprises.

Implementation of Corporate Social Responsibility in SOEs, are followed by the Decree. SOE Kep-236 / MBU / 2003 jo. Candy. SOE No.Per-05 / MBU / 2007, so it has the main points of thought or consideration as follows:

1. Given that one of the purposes and objectives of the establishment of state-owned enterprises are participating actively provide guidance and assistance to small entrepreneurs group, cooperatives, and community, the SOEs can set aside part of net income for the purposes of fostering of small co-operatives and community development around the SOE.

2. Company and Housing of the Government (SOEs) shall implement the Partnership Program and Community Development Program, while for SOEs Persero Open implementation of the Partnership and Community Development can refer to the implementation of the Partnership Program and Community Development Program at Persero and Perum (Non Open SOE).

Partnership Program with Small Entrepreneurs and Community Development Program fistly set in Permeneg SOE No. 236 / MBU / 2003 on SOEs. Siace as set this gao regulation not adequately operational basis for implementing enterprise BUMN Partnership program with a Small Business and Community Development Program, then Permeneg SOE No. 236 / MBU / 2003 on SOE replaced by Permeneg SOE No. PER-05 / MBU / 2007 aboit SOE Partnership Program with Small Entrepreneurs and Community Development Program, April 27, 2007. The government will support companies that has social concern.

By paying attention to the benefits of CSR, most companies in the city of Bogor has implemented CSR. Mayor of Bogor, Dr. Bima Arya asserted, CSR program in the city of Bogor conducted by enterprises or private companies are already running, but it has not integrated yet still walk on their own. City Government considers that the CSR program that had been distributed a number of companies have not had a significant impact on the city of Bogor and surrounding communities.

That case becoume the background for the emergence of the concept of Corporate Social Responsibility, especially in the city of Bogor. Charity activity basically has become a tradition and customs of the people of Indonesia, especially based on the teachings of religion. Today Corporate Social Responsibility has developed quite rapidly. One driving force is a paradigm shift for the business world is not solely for profit, but it must also behave ethically and contribute to the creation of a social investment. Yusuf Wibisono (2007: 71) which is commonly done by companies which are doing charitable, philanthropic and organizing community development programs (community development).

This study is an evaluation research because it is the general aim of this study is to assess the benefits, contributions, and the feasibility of CSR programs are undertaken by companies and enterprises in the city of Bogor, to discover and develop and enhance program implementation of CSR is right on target for the company as well as for its stakeholders, including the government. In particular the research objectives are as follows:

Assess the goal-setting, the profile of the beneficiary and the basic programming of CSR by companies and enterprises to the needs of beneficiaries; Review the company's support and structural aspects of the organization, qualification and financing program leaders; Assess the implementation of CSR programs in terms of understanding the program by beneficiaries, use of budgets and monitoring; Reviewing the results of the implementation of CSR programs for companies, beneficiary communities, and governments. The difference in the research done by the Mukti Dawn compared to 
this study, namely:. The focus and Fajar Mukti research was to determine the setting of corporate social responsibility.

Fajar Mukti research suggested the government to amend the Law on Investment and Company Law in order to have the same meaning, which is actually right Iebih Corporate Social Responsibility is not regulated in the legal sphere.

Corporate Social Responsibility research results and various aspects, social, legal and financial, evaluation research reinforced the need for the implementation of CSR at private companies and SOEs, in order to provide an assessment of the implementation of the program and provide advince model of csr that would provide the optimal benefits for companis and their stakeholders

Other research relevant David Ariansyah, The implentation of Corporate Social Responsibility and Cultural Organization in PDAM Tirta Pakuan Bogor and The Influence of Community Satisfaction in Bogor. (Implementation of Corporate Social Responsibility and Cultural Organization on PDAM Tirta Pakuan Bogor Effect on Public Satisfaction Bogor City

There are differences in research conducted by David Ariansyah with this research.

1. David Ariansyah research focuses on the impact felt by the company after conducting Corporate Social Responsibility both in terms of internal (corporate culture) and external (reputation).

2. David Ariansyah research does not provide improvement suggestions collaborative model of Corporate Social Responsibility intact so as to create responsible and sustainable relationship between the company and its stakeholders, especially the public and the government.

\section{METHODS}

The method used in research in PDAM Tirta Pakuan are evaluative research methods, with the CIPP evaluation model. CIPP evaluation model which stands for: Context evaluation, input evaluation, Evaluation Process and Product evaluation. Fourth abbreviation of the CIPP that is the evaluation component.

CIPP evaluation model used in the study in PDAM Tirta Pakuan is because it is more comprehensive and effective in describing, obtaining and providing useful information for judging decision alternatives. Comprehensive evaluation model CIPP Iebih among other evaluation models, because the object of evaluation is not just the product itself but also include context, input, process, and outcome. The concept of this Stufflebeam view that an important purpose of evaluation is not to prove, but to improve. The substance and methods of evaluation will provide an assessment of "good-bad" or "success-failure" with regard to the state of achievement of the work program, so that the results of the evaluation is objective and useful, so this assessment is strongly emphasized the importance of ethics and approaches reliable.

Qualitative researchers as a human instrument, serves to fix the focus of research, selecting informants as a source of data, collecting data, assessing data quality, data analysis, interpret the data and make conclusions on the findings. While the process of collecting primary data and secondary data in this study carried out through the following activities: observation interviews, documentation and triangulation

\section{Table 1. Item Evaluation Criteria In accordance Interview Questions Implementation of Corporate Social Responsibility Program in enterprises taps Tirta Pakuan Bogor Based Model CIPP}




\section{component \\ Evaluation}

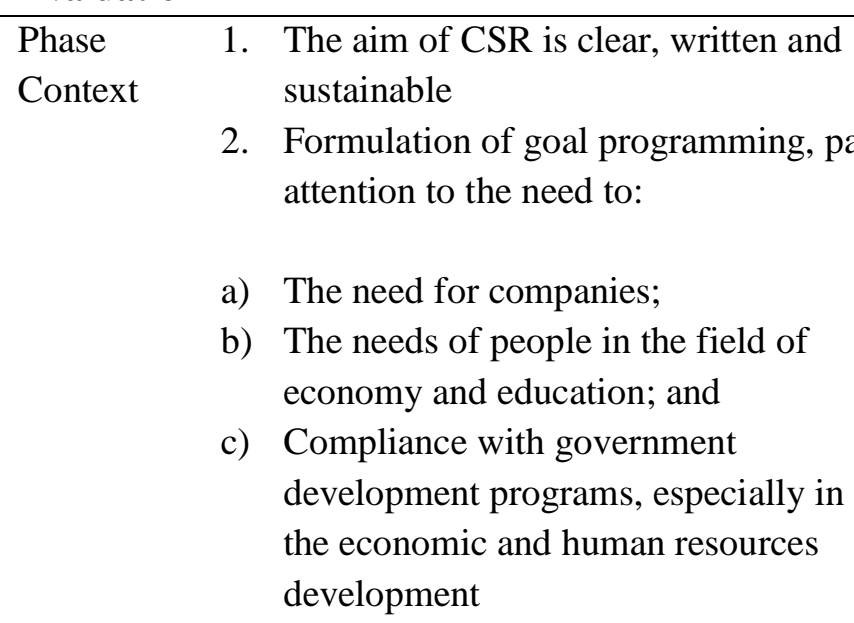

\section{Beads Questions}

1. What is the aim of implementing CSR programs in the company?

2. Does the company carry out the formulation of the program objectives by taking into account the needs of companies, communities and governments, especially in economics, human resource development, and government programs?

3. There is a preparation program have 1. How is the reference used in the preparation of baselines that is clear both from the CSR in the company program? management and legal

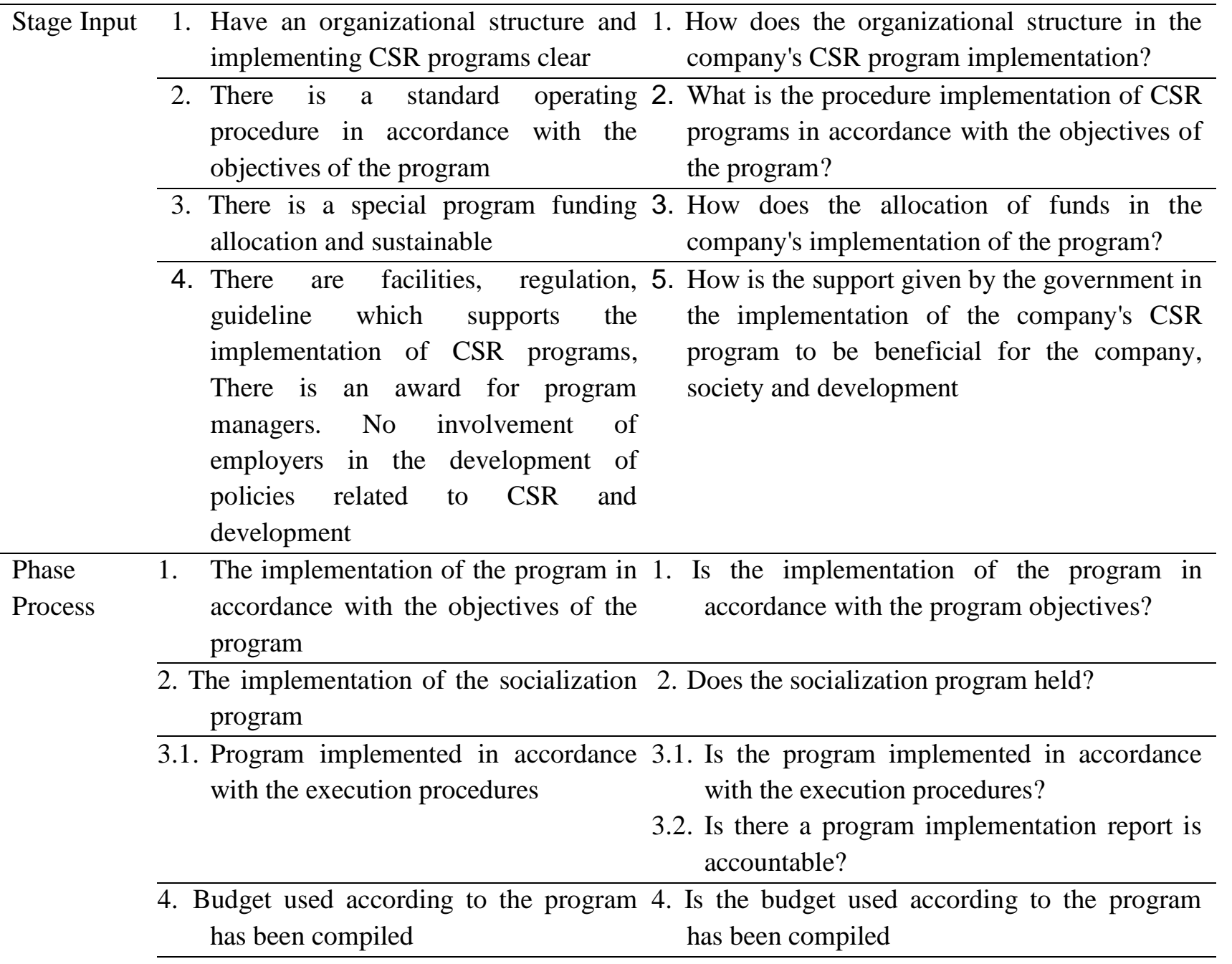


5.1. There is a team supervisor / evaluator 5.1. Is there a team supervisor / evaluator of the implementation of a credible program program credible?

5.2. CSR reports in addition submitted to 5.2. Is CSR reports in addition submitted to shareholders was also submitted to shareholders was also submitted to external external stakeholders, especially stakeholders, especially governments? government

stage 1. Imaging company towards positive 1. Is the company towards stakeholders Imaging Product stakeholders positive?

2. There is no social conflict on society 2. Is there a social conflict to the community?

3. The company grows and develops 3. Does the company grow and thrive?

4.1. Programs considered beneficial for 4.1. Is the program considered beneficial to society society?

4.2. 4.2. The quality of human resources in 4.2. Is increased human resources in the the community increased community?

4.3. Increase the community's economy 4.3. Is the community's economy increased?

5.1. CSR programs considered beneficial 5.1. Is CSR program considered beneficial for for development in the city of Bogor development in the city of Bogor?

5.2. The quality of human resources in the 5.2. Is the quality of human resources in the city city of Bogor increased of Bogor increased?

5.3. The community's economy increased 5.3. Is the community's economy increased social social problems decreased problems decreased?

Analysis of the data used in this study using qualitative data analysis. The data analysis of qualitative research refers to the model introduced by Miles and Huberman (1992: 16), which define the analysis in three streams of activity, namely the reduction of the data (data reduction), presentation of data (data display), and conclusion / verification (conclusion drawing / verification).

Martthew B. Miles and A. Michael Huberman (1994: 8-12) Flow analysis of the data in question, can be seen in the image below. Each of these stages are described as follows:

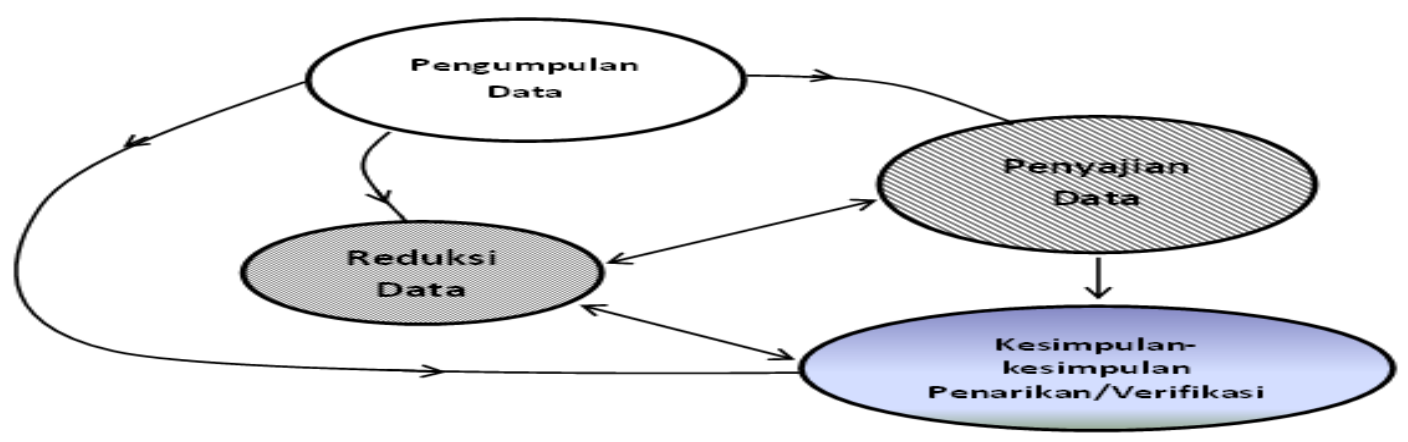

Source: Miles and Huberman (1994: 12)

Figure 1. Visual Flow Data Analysis

\section{DISCUSSION}

Bogor City is one city that is strategically located geographically visits because located between the Provincial Capital and the Capital City of Indonesia. So that the Bogor city as a center of trade and services are experiencing rapid growth in the field of business and economy 
Whereas the reference preparation Partnership Program and Community Development in PDAM Tirta Pakuan Bogor is as follows:

Table 2. Preparation of CSR enterprises reference PDAM Tirta Pakuan

\begin{tabular}{|c|c|c|c|}
\hline No & basic guidelines & year & about \\
\hline 1 & $\begin{array}{l}\text { Undang- Undang } \\
\text { No. } 40\end{array}$ & 2007 & Company Limited \\
\hline 2 & $\begin{array}{l}\text { Undang- Undang } \\
\text { No. } 25\end{array}$ & 2007 & $\begin{array}{l}\text { on Investment, while the contents of the Act } \\
\text { relating to CSR }\end{array}$ \\
\hline 3 & $\begin{array}{l}\text { Undang- Undang } \\
\text { No. } 19\end{array}$ & 2003 & State-owned Enterprises \\
\hline 4 & PP No. 47 & 2012 & Corporate Social Responsibility \\
\hline 5 & $\begin{array}{l}\text { Peraturan Menteri } \\
\text { BUMN No. Per- } \\
5 / \mathrm{MBU} / 2007\end{array}$ & 2007 & $\begin{array}{l}\text { Partnership Program and Community } \\
\text { Development }\end{array}$ \\
\hline 6 & $\begin{array}{l}\text { Peraturan Menteri } \\
\text { BUMN No. Per- } \\
\text { 20/MBU/2012 }\end{array}$ & 2012 & $\begin{array}{l}\text { Amendment to the Regulation of the State } \\
\text { Minister for State Owned Enterprises No. Per-05 } \\
\text { / MBU / } 2007 \text { on the Partnership Program for } \\
\text { State Owned Enterprises With Small Business } \\
\text { and Community Development }\end{array}$ \\
\hline 7 & $\begin{array}{l}\text { Kepmen BUMN } \\
\text { No. Kep } \\
\text { 100/MBU/2002 }\end{array}$ & 2002 & $\begin{array}{l}\text { Evaluation of Health State-Owned Enterprises } \\
\text { Minister for State Owned Enterprises }\end{array}$ \\
\hline 8 & $\begin{array}{l}\text { Perda Nomor } 17 \\
\text { Tahun } 20011 \text { Pasal } \\
16 \text { Lembaran } \\
\text { Daerah Kota Bogor } \\
\text { Tahun } 2011 \text { Nomor } \\
5 \text { Seri E }\end{array}$ & 2011 & $\begin{array}{l}\text { Board of Directors has the following tasks: a. } \\
\text { planning, coordination and supervision of all } \\
\text { operational activities; b. fostering employee; c. } \\
\text { administer and manage the wealth of taps; } d \text {. } \\
\text { organizing public administration and finance; e. } \\
\text { prepare a Strategic Plan Business (bussiness } \\
\text { plan / corporate plan) } 5 \text { (five) year authorized by } \\
\text { the Mayor through the proposal of the } \\
\text { Supervisory Board; f. prepare and submit a } \\
\text { Business Plan and Annual Budget taps which is } \\
\text { the annual elaboration of the Strategic Plan } \\
\text { Business (bussiness plan / corporate plan) to the } \\
\text { Mayor by the Supervisory Board; g. prepare and } \\
\text { submit a report of all activities PDAM }\end{array}$ \\
\hline 8 & $\begin{array}{l}\text { Peraturan Walikota } \\
\text { No } 49 \text { Tahun } 2013\end{array}$ & 2013 & Organ and Civil PDAM Tirta Pakuan Bogor \\
\hline 9 & $\begin{array}{l}\text { Perwali No } 23 \\
\text { Tahun } 2013\end{array}$ & 2013 & $\begin{array}{l}\text { General Guidelines for Procurement of Goods / } \\
\text { Services in local enterprises in Bogor municipal } \\
\text { government environment }\end{array}$ \\
\hline 10 & $\begin{array}{l}\text { Perwali No } 25 \\
\text { Tahun } 2013\end{array}$ & 2013 & $\begin{array}{l}\text { Organizational Structure and Work Procedure } \\
\text { PDAM Tirta Pakuan Bogor. }\end{array}$ \\
\hline
\end{tabular}




\begin{tabular}{lll}
\hline \multicolumn{1}{l}{$\begin{array}{l}\text { Peraturan } \\
\text { Daerah Kota Bogor } \\
\text { Nomor 8 Tahun } \\
\text { 2011. }\end{array}$} & 2011 & $\begin{array}{l}\text { ROE Partnership Program Guidelines With } \\
\text { Small Business and Community Development } \\
\text { Program (CSR) PDAM Tirta Pakuan Bogor }\end{array}$ \\
& $\begin{array}{l}\text { Guidelines for the implementation of the } \\
\text { National Program for Community } \\
\text { Empowerment (PDPM) districts and villages of } \\
\text { the fiscal year }\end{array}$
\end{tabular}

The legal basis when viewed in terms of strength, has been very strong for the implementation of the CSR program to carry out their duties. This is evidenced by the approval of the Regional Budget (APBD) for the implementation of CSR programs in the city of Bogor in 2016 allocated 10 billion, while the city of Bogor PDAM Tirta Pakuan also budgeted 3.5 billion for CSR activities.

From a study of enterprises PDAM Tirta Pakuan Bogor City has been implementing Corporate Social Responsibility in the city of Bogor, West Java Province, researchers presented the findings of the evaluation results in 4 tahab program evaluation model of CIPP is tahab Context, Input, Process, and Product, as follows:

\section{a. Evaluasi Context}

Table 3. Discussion of Context Based Evaluation Criteria Program Evaluation CSR in PDAM Tirta Pakuan Bogor

\begin{tabular}{|c|c|c|c|c|c|c|c|}
\hline \multirow{2}{*}{$\begin{array}{c}\text { Aspects } \\
\text { Evaluated }\end{array}$} & \multirow{2}{*}{ Evaluation criteria } & \multicolumn{2}{|c|}{$\begin{array}{c}\text { Informati } \\
\text { on } \\
\end{array}$} & \multirow{2}{*}{ Evaluation findings } & \multicolumn{2}{|c|}{ Ranked } & \multirow{2}{*}{ Decision } \\
\hline & & $\begin{array}{l}\text { there } \\
\text { is }\end{array}$ & $\begin{array}{l}\mathrm{N} \\
\mathrm{o}\end{array}$ & & L S & $\mathrm{H}$ & \\
\hline $\begin{array}{l}\text { 1. The } \\
\text { purpose } \\
\text { of the } \\
\text { program }\end{array}$ & $\begin{array}{l}\text { 1. CSR } \\
\text { implementation goals } \\
\text { clear, written and } \\
\text { sustainable. } \\
\text { 2. The formulation of } \\
\text { the purpose of the } \\
\text { program, taking into } \\
\text { account: } \\
\text { a) The need for } \\
\text { companies } \\
\text { b) The need for } \\
\text { community economic } \\
\text { and educational fields; } \\
\text { c) Compliance with } \\
\text { government } \\
\text { development } \\
\text { programs, especially } \\
\text { in the economic and } \\
\text { educational fields. }\end{array}$ & $\sqrt{ }$ & & $\begin{array}{l}\text { 1. Having a goal CSR } \\
\text { program called } \\
\text { Partnership, clearly } \\
\text { and in writing. } \\
\text { 2. Programming is done } \\
\text { by assessing the } \\
\text { needs of the } \\
\text { community, and } \\
\text { considering the } \\
\text { interest of the } \\
\text { company, and the } \\
\text { government. The } \\
\text { program is designed } \\
\text { not provide direct } \\
\text { benefits to the } \\
\text { company and } \\
\text { emphasized on } \\
\text { regional anars on }\end{array}$ & & & $\begin{array}{l}\text { The evaluation } \\
\text { criteria are met, } \\
\text { ratings are } \\
\text { categorized as } \\
\text { "high" so that } \\
\text { aspect of the } \\
\text { purpose of the } \\
\text { Partnership taps } \\
\text { can be } \\
\text { maintained and } \\
\text { developed }\end{array}$ \\
\hline
\end{tabular}




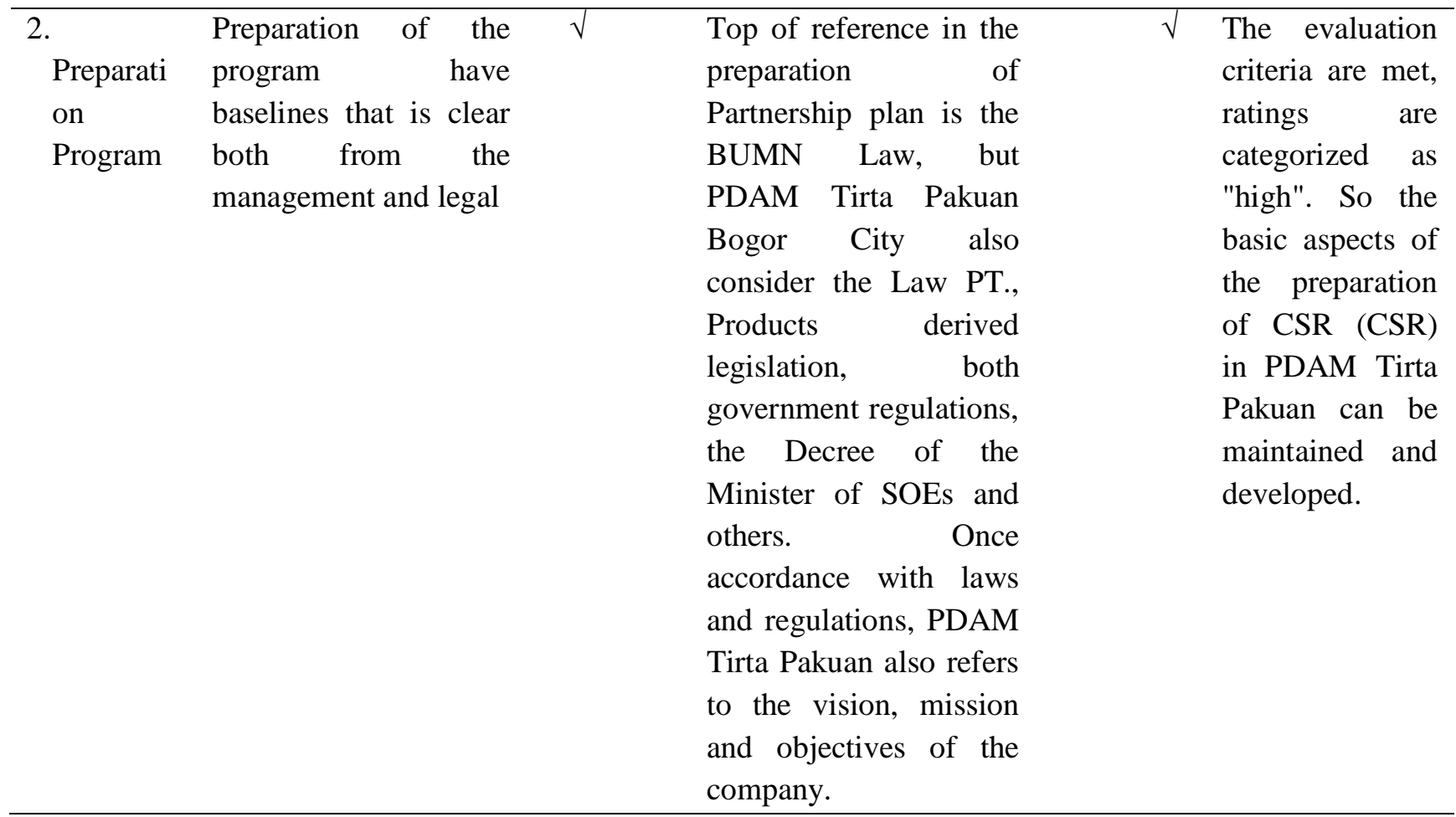

Information : $\mathrm{L}=$ low, $\mathrm{S}=$ Secondary, $\mathrm{H}=$ High

\section{b. Input evaluation (Input)}

Table 4. Discussion Evaluation Criteria Evaluation Based Input CSR Program PDAM Tirta Pakuan Bogor

\begin{tabular}{|c|c|c|c|c|c|c|}
\hline \multirow{2}{*}{$\begin{array}{l}\text { Aspects } \\
\text { Evaluated }\end{array}$} & \multirow{2}{*}{$\begin{array}{l}\text { Evaluation } \\
\text { criteria }\end{array}$} & \multicolumn{2}{|c|}{$\begin{array}{l}\text { Informati } \\
\text { on }\end{array}$} & \multirow{2}{*}{ Evaluation findings } & Ranked & \multirow{2}{*}{ Decision } \\
\hline & & $\begin{array}{l}\text { ther } \\
\mathrm{e} \text { is }\end{array}$ & No & & $\mathrm{L} S \mathrm{H}$ & \\
\hline $\begin{array}{l}1 . \quad \text { The } \\
\text { organizationa } \\
1 \quad \text { structure }\end{array}$ & $\begin{array}{l}\text { Organization } \\
\text { al structure } \\
\text { and }\end{array}$ & $\sqrt{ }$ & & $\begin{array}{l}\text { In Bogor PDAM Tirta Pakuan } \\
\text { managed by the Partnership and } \\
\text { the General in charge of Human }\end{array}$ & $\sqrt{ }$ & $\begin{array}{l}\text { The evaluation } \\
\text { criteria are met, } \\
\text { dikategoriakn }\end{array}$ \\
\hline $\begin{array}{l}\text { and } \\
\text { implementati } \\
\text { on of CSR } \\
\text { programs }\end{array}$ & $\begin{array}{l}\text { implementati } \\
\text { on of CSR } \\
\text { programs } \\
\text { clearly. }\end{array}$ & & & $\begin{array}{l}\text { Resources and General Director. } \\
\text { Thus the results of the } \\
\text { evaluation showed that PDAM } \\
\text { Tirta Pakuan Bogor has an } \\
\text { organizational } \\
\text { implementing CSR programs } \\
\text { are clear. }\end{array}$ & & $\begin{array}{l}\text { vote "high. } \\
\text { Decision could } \\
\text { be made that } \\
\text { aspect of } \\
\text { support for the } \\
\text { organizational } \\
\text { structure in the } \\
\text { city of Bogor } \\
\text { PDAM Tirta } \\
\text { Pakuan can } \\
\text { dipertaankan } \\
\text { and developed. }\end{array}$ \\
\hline
\end{tabular}




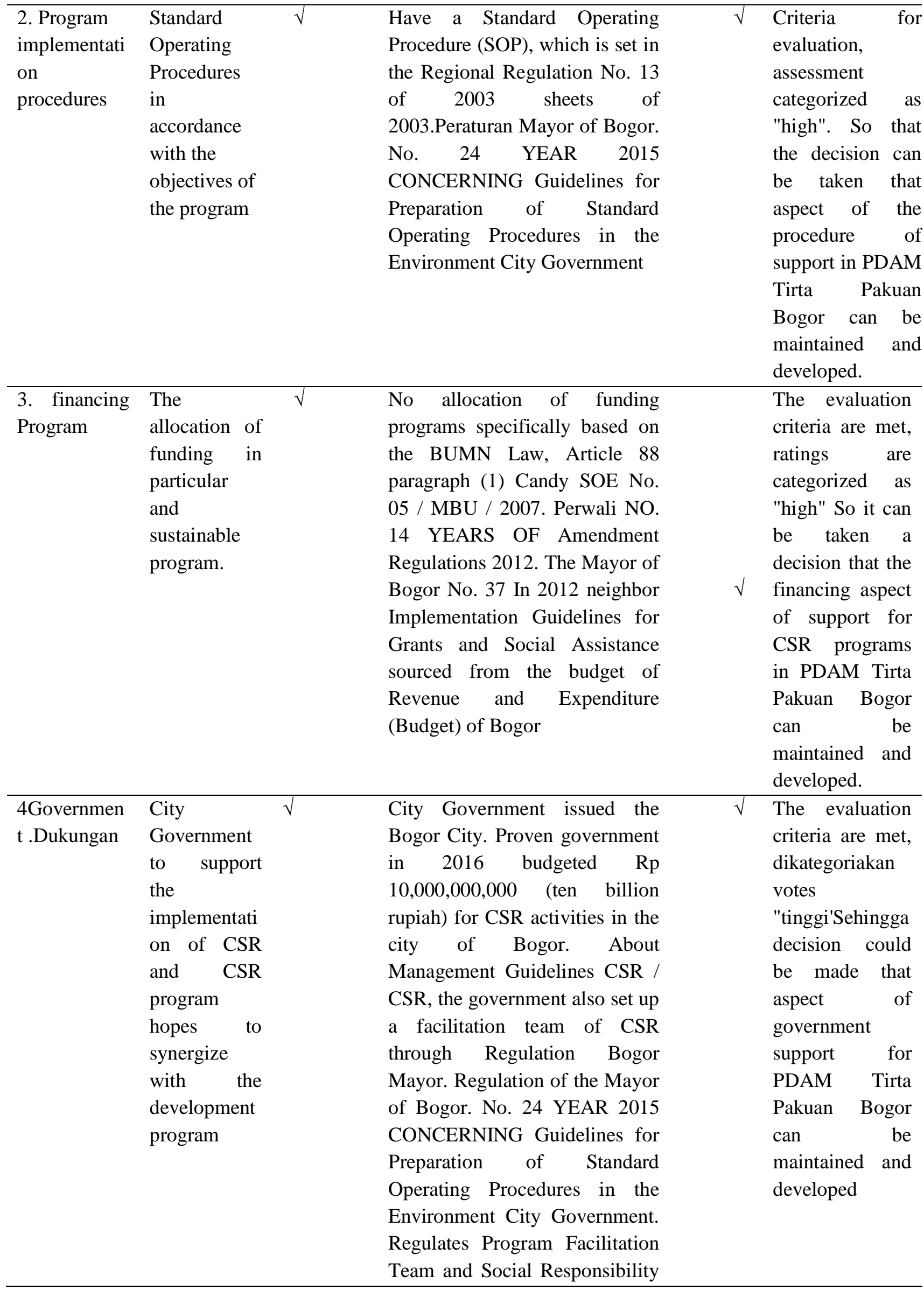


Program for the Environment

(Corporate Social

Responsibility) Bogor City.

c. Evaluasi Process (Proses)

Table. 5. Discussion Evaluation Criteria Evaluation Process Based on CSR Program PDAM

Tirta Pakuan Bogor

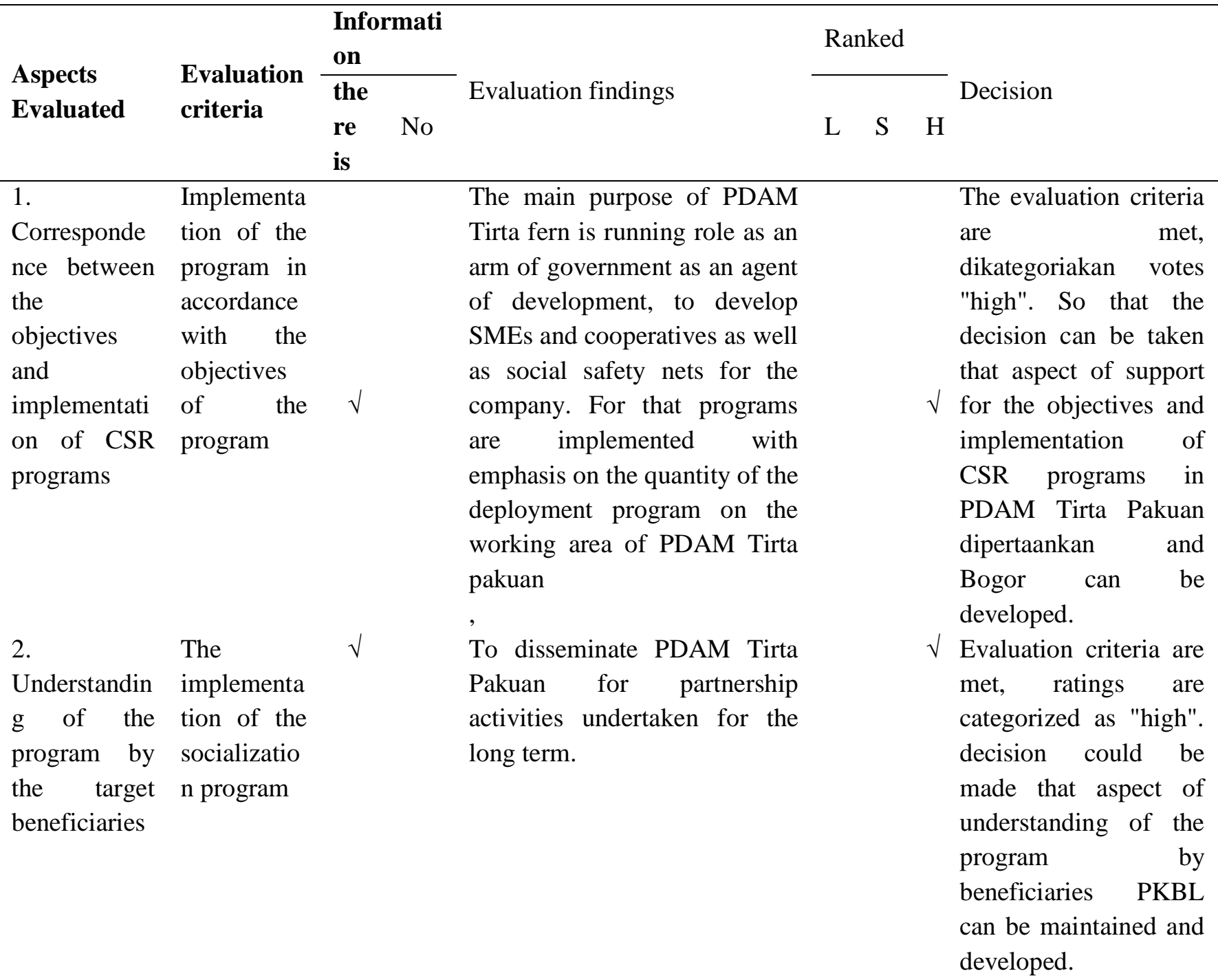


3.

$\begin{array}{ll}\text { implementati } & \begin{array}{l}\text { implemente } \\ \text { on Program }\end{array} \\ & \mathrm{d} \quad \text { in } \\ & \begin{array}{l}\text { accordance } \\ \text { with the } \\ \text { execution } \\ \text { procedures. }\end{array} \\ & \\ & \\ \text { 2.Laporan } \\ \text { accountable } \\ \text { program } \\ \text { implementa } \\ \text { tion }\end{array}$

$\begin{array}{ll}\text { 4. Financing } & \text { Budget } \\ & \text { used } \\ \text { according } & \\ \text { to the } & \\ \text { program } & \text { that has } \sqrt{ } \\ & \text { been } \\ & \text { compiled. }\end{array}$

5.. $\quad 1$. There is

Supervision a team

of the supervisor /

implementati evaluator

on of the implementa

program tion of a

credible

program.

\section{2.}

Distributio

$\mathrm{n}$ and

publication

of CSR

reports to

internal and

external

stakeholder

s.
Partnership has been implemented as intended. PDAM Tirta pakuan got a score of 3 (three) for the distribution of funds and the loan collectibility. Independent agency of the results of the survey, $98.17 \%$ (ninety front coma seventeen percent) of respondents said the types of CSR activities PDAM Tirta ferns in the city of Bogor in accordance with the type of requirement.

PDAM Tirta pakuan prepared a report on CSR activities program are audited by an independent auditor.

The budget has been prepared in RKA realized according to the budget plan. In accordance with existing mechanisms.

To supervise the implementation of the program, in addition to using internal organizational accountability mechanisms, PDAM Tirta pakuan conduct audits were performed using the independent audit.

The report is distributed to stakeholders internal and external to the government, especially the city of Bogor.
The evaluation criteria are met, ratings are categorized as "high"

$\sqrt{ }$ can be taken a decision that aspect of the program can be maintained and developed.
The evaluation criteria $\checkmark$ vot votes "tinggi'Sehingga decision could be made that the financing aspects of CSR in PDAM Tirta dipertahanakan and ferns can be developed.

Findings tehadap aspect evaluated has met the criteria of evaluation, assessment dikategoriakan "tinggi'Sehingga decision could be made that aspects of monitoring the implementation of the program in PDAM Tirta ferns can be maintained and developed. 


\section{d. Product (Produk)}

Table. 6. Discussion Based Product Evaluation Program Evaluation Criteria CSR PDAM Tirta Pakuan Bogor

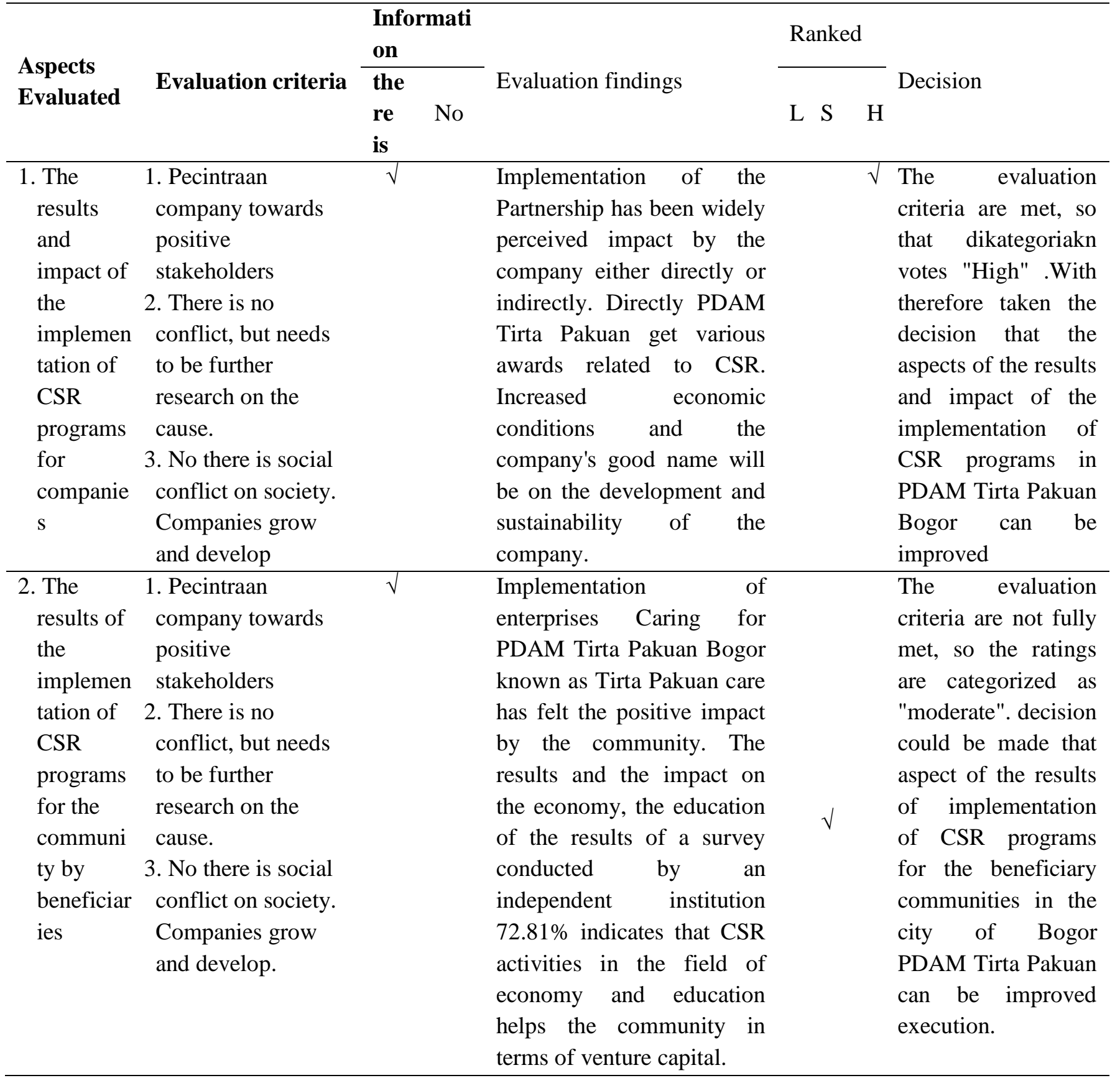




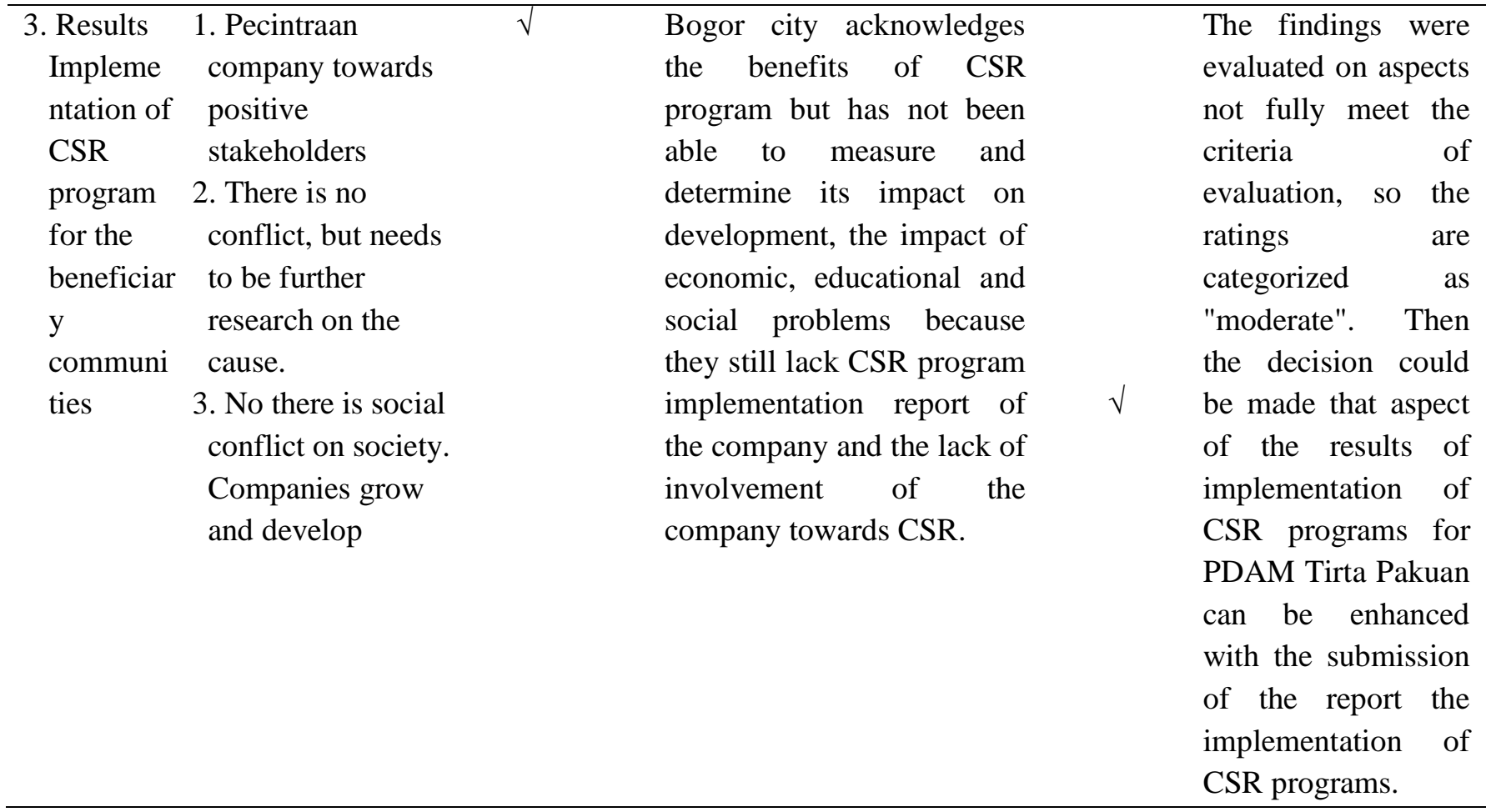

\section{CONCLUSIONS}

Based on the findings and discussion of the evaluation results by taking into account the model used in this study, the conclusions of the study were presented by tahaban CIPP evaluation model as follows

a. Context Evaluation of the results, concluded:

Setting goals and basic preparation of its Corporate Social Responsibility by PDAM Tirta enterprises Pakuan Bogor for the Partnership Program and Community Development Bogor PDAM Tirta Pakuan has a goal and a clear program and writing as well as observe the interest of the company, the community and government. The planning PKBLPDAM Tirta Pakuan Bogor based on legislation for SOE,

Limited and its implementing provisions refers to the vision, mission, programs and strategies PDAM Tirta Pakuan Bogor.

b. Input Evaluation results, concluded:

1) PDAM Tirta Pakuan Bogor has the support of the company's resources, both from the organizational structure, organizational structure and qualifications of its own person in charge of the program, procedures for implementing the programs and funding from the program profit.

2) the City Government to support the implementation of CSR and CSR program hopes to synergize with the development program in the city of Bogor. The support is the establishment 
of CSR facilitation team Bogor City guide line synergy Corporate Social Responsibility and plans related to CSR award. But support was not yet fully implemented because there are still differences of understanding.

c. Process Evaluation of the results, concluded:

Implementation of CSR / CSR by PDAM Tirta Pakuan Bogor has been conducted in accordance with the purpose of the program, understood by the majority of beneficiaries. Program budget has been used in accordance with the objectives and has made monitoring the implementation of the program both internally and externally on its independence. PDAM Tirta Pakuan Bogor City also submit a report to the local government implementation of the program of Bogor.

d. Product Evaluation of the results, concluded:

The results of the implementation of the program CSR / CSR at PDAM Tirta Pakuan Bogor has been widely perceived impact by the company, either directly or indirectly. Directly, PDAM Tirta Pakuan Bogor received various awards related to CSR. Increased of economic conditions of PDAM Tirta Pakuan and good name will be ensure the development and sustainability (sustainability) company. The results of the implementation of CSR at PDAM Tirta Pakuan Bogor for the beneficiary communities known as Tirta Pakuan Cares positive impact has been felt by the community. This is evident from the results of a survey conducted by an independent agency, which showed $67.15 \%$ (sixty seven point fifteen percent) activities of the Partnership Program and Community Development economics helps the community in terms of venture capital. In general, the City Government recognizes the benefits of implementing CSR programs PDAM Tirta Pakuan Bogor City, but has not been able to measure and determine its impact on development, the economy, education and social issues because they still lack implementation report Corporate Social Responsibility program of the company.

\section{REFERENCES}

Arikunto, Suharsimi dan Cepi Sa fruddin Abdul Jabar, Evaluasi Program Pendidikan Pedoman Teoritis Praktis bagi Praktisi Pendidikan. Jakarta: Bumi Aksara, 2004.

Canadian International Development Agency. Evaluation of the Canadian Francophonie Scholarship Program (CFSP).1987-2005,Quebec Canada, Desember 2005. (diakses, 8 Juli 2013)

Chen, Huey-Tsyh. Practical Program Evaluation: Assessing and Improving Planning, Implementation and Effectiveness. California: Sage Publication. Inc., 2005

Daniel L. Stufflebeam. The CIPP Model for Evaluation. Precented at The Annual Conference of The Oregon Program Evaluators Network, 2003. (diakses $14 \quad$ April 2013)

Daymon, Christine, Metode-metode Riset Kualitatif dalam Public Relations dan Marketing,Communications/Christine Daymon \& Immy Holloway; penerjemah Cahya Wiratama, penyuting, SantiIndra Astuti- Yogyakarta: Bentang 2008.

Denzin, N.K., \& Yvonna S.Lincoln,. Handbook of Qualitative Research, terjemahan Dariyanto, Badrus Samsul Fata, Abi, John Rinaldi, Penerbit Pustaka Pelajar, 2009

Djaali, Muljono dan Pudji. Pengukuran dalam Bidang Pendidikan. Jakarta: Grasindo, 2008.

Fajar, Mukti. Tanggung Jawab Sosial Perusahaan di Indonesia: Studi tentang Penerapan Ketentuan CSR pada Perusahaan Multinasional, Swasta Nasional \& BUMN di Indonesia. Jakarta: Pustaka Pelajar, 2010.

Gray, R., R. Kouhy, dan S. Lavers. Corporate Social and Environmental Reporting. A Review of the Literature and a Longitudinal Study of UK Disclosure. Accounting, Auditing and Accountability Journal. Vol. 8. No. 2. UK, 1995.

Hadi, Nor. Corporate Social Responsibility. Yogyakarta: Graha Ilmu, 2011. 
Jody L. Fitzpatrick, James R. Sanders dan Blaine R. Worthen. Program Evaluation: Alternative Approaches and Practical Guildelines. New York: Pearson Education, 2004.

Kartini, Dwi. Corporate Social Responsibility. Bandung: Refika Aditama, 2009.

Mc Namara, Carter, A Basic Guide to Program Evaluation, Authenticity Consulting, $\quad$ LLC, 2002 (diakses, 24 Juni 2012)

Miles, Martthew B. dan A. Michael Huberman. Qualitative Data Analysis. $\quad$ London: SAGE Publications, 1994.

Mursitama dkk, Tirta N. Corporate Social Responsibility di Indonesia, Teori dan Implementasi: Studi Kasus Community Development Riaupulp. Jakarta: Institute for Development of Economic and Finance, 2011.

Popham, W. James. Educational Evaluation. New Jersey: Prentice Hall. Inc., 1974.

Prayogo, Dody. Evaluasi Program Corporate Social Responsibility Dan Community Development Pada Industri Tambang Dan Migas. Makara, Sosial Humaniora, Vol. 15, No. 1, Juli 2011.

Purwosutjipto, H.M.N. Pengertian Pokok Hukum Dagang (3) Hukum Pengangkutan. $\quad$ Jakarta: Djambatan, 1995.

Rachman, Nurdizal M. Panduan Lengkap Perencanaan CS. Jakarta: Penebar Swadaya, 2011.

Royse, David, Bruce Thyer dan Deborah Padgett. Program Evaluation: An Introduction. Massachusetts: Wadsworth, 2010.

Shinkfield, Daniel L. Stufflebeam dan Anthony J. Systematic Evaluation A Self Instructional Guide to Theory and Practice. Boston: Kluwer Nijhoff Publishing, 1986.

S. Eko Putro Widoyoko, Rvaluasi Program Pembelajaran, Paduan Praktis $\quad$ Bagi $\quad$ Pendidik dan Calon Pendidik, Penerbit Pustaka Pelajar, Yogyakarta, 2011

Stella Tan, Nicolette Lee, and David Hall CIPP as a model for evaluating learning spaces, Swinburne University of Technology 2010.

Shinkfield, Daniel L. Stufflebeam dan Anthony J. Evaluation Theory, Models \& Applications. San Francisco: Jossey- Bass, 227.

Stake, R.E. Evaluating the arts in education: A responsive approach. Ohio: Charles E. Merrill Publishing Company, 1975.

Susanto, A.B. Strategic Management Approach Corporate Social Jakarta Consulting Group, 2007.

Tjakranegara, Soegijatno. Hukum Pengangkutan Barang dan Penumpang. Jakarta: Rineka Cipta, 1995.

Visser, Wayne, The Age of Responsibility: CSR 2.0 and the New DNA of Business. United Kingdom: John Wiley \& Sons Ltd, 2011.

Weber, Andrew W. Savitz dan Karl. Triple Bottom Line. San Francisco: Jossey- Bass, 2006.

Werther Jr., William dan David Chandler, Strategic Corporate Social Responsibility: Stakeholders in a Global Environment, USA, 2011. 
Wether, William. B, Jr. dan David Chandler. Strategic Corporate Social Responsibility. USA: Sage Publication Inc., 2011.

Widoyoko, Eko Putro. Evaluasi Program Pembelajaran: Panduan Praktis $\quad$ Bagi $\quad$ Pendidik dan Calon Pendidik, Pustaka Belajar, 2012.

Yusuf, Wibisono. Membedah Konsep dan Aplikasi CSR. Gresik: Fascho Publishing, 2007.

ISO/FDIS 26000: Guidance on Social Responsibility (Geneva: 2010). 